\title{
Proyecciones y Ramificaciones del Deseo en "Junto al Río de Cenizas de Rosa"
}

Una visión global de "Junto al Río de Cenizas de Rosa" permite identificar en el casi obliterado nivel anecdótico una parodia de relato que sigue una lógica narrativa caracterizada por ciertas constantes fácilmente identificables. Desde un principio Severo Sarduy hace patente la presencia de dos elementos íntimamente relacionados que funcionan como una entidad repetitiva dentro del ciclo narrativo: un perseguidor y el objeto de su persecución. La correspondencia entre estas dos entidades es recíproca ya que el General (perseguidor) existe en función de Flor de Loto (el objeto de su pasión) y ésta a su vez es una recreación del deseo insatisfecho del militar. Dicha relación se mantiene constante hasta que el General, agobiado por una serie de fracasos, trata de satisfacer su deseo por medio de substituciones que consisten en reemplazar la imagen espectral de Flor de Loto por figuras más concretas: Auxilio y Socorro, con quienes copula al unisono, y María Eng (la réplica de Flor de Loto), quien, como su doble, se le escapa. Persiste, sin embargo, en el anhelo de apagar su lujuria y, frustrado, entra en una etapa de contemplación y autosatisfacción al convertirse en voyeur. Es durante esta faceta cuando es sorprendido por Carita de Tortura (aliado de Flor de Loto), quien lo atormenta arrancándole una uña. En ese instante su papel se invierte y de perseguidor-mirón pasa a perseguido-torturado. La tortura a manos de su adversario cambia el giro del relato porque, aunque el General se nos presenta dentro de la misma constante que lo ha caracterizado a lo largo del episodio-- persiguiendo al objeto que le apasiona--, su motivación se hace ahora negativa. Pasa de una primera etapa sádica (mirón) al estado completo y final de sadismo: decide herir a Flor de Loto al no poderla poseer y al reconocer que "el placer está atravesado por el dolor". . "

1 La novela más conocida de Severo Sarduy, y una de las más heterodoxas de la novelística cubana, es $D e$ donde son los cantantes (1967). Dividida en tres relatos principales-- "Junto al Río de Cenizas de Rosa", "La Dolores Rondon" ' y "La entrada de Cristo en La Habana"--, la obra se presta a ser estudiada siguiendo la división que le ha asignado su autor. Los episodios forman mundos autóctonos, metáforas de cada una de las tres culturas (la china, la negra y la blanca) que Sarduy considera parte integral de lo cubano. Con esto en mente, hemos considerado apropiado estudiar cada relato por separado para así adentrarnos más libremente en un análisis de sus elementos constitutivos. "Proyecciones y ramificaciones del deseo en 'Junto al Río de Cenizas de Rosa' " forma, por lo tanto, parte de un proyecto más amplio en el que buscamos analizar a fondo $D e$ donde son los cantantes, novela que marca un giro radical en la narrativa hispanoamericana.

" Severo Sarduy, "Junto al Río de Cenizas de Rosa", en De donde son los cantantes, 2 a ed. (México: Joaquín Mortiz, 1970), p. 53. A esta edición se refieren las páginas que se indican entre paréntesis después de cada cita. 
Desde esa perspectiva notamos que en "Junto al Río de Cenizas de Rosa", el deseo es la unidad base de la cual se proyectan y ramifican las diferentes facetas del relato, así como las múltiples situaciones por las que atraviesa el caricaturesco y libidinoso General en busca de los favores de Flor. La travesía del militar brinda al autor la oportunidad de intercalar en el episodio los elementos que considera más significativos del mundo chino: el aludido deseo, el estatismo y la acción extrema. ${ }^{3}$ Pensamos que si hay que proponer una hipótesis de trabajo a la exégesis de un mundo que ofrece posibilidades ad infinitum, lo más adecuado es descubrir cómo se manifiestan y dónde se encuentran los tres elementos anteriormente mencionados. Para llevar a cabo este objetivo seguiremos el orden anecdótico del episodio, adentrándonos frecuentemente en los variados aspectos de la antigua erotología y arte chinos que indudablemente han servido de cantera al autor en la disposición de sus imágenes. Este procedimiento no sólo permitirá elucidar el elusivo relato, sino que señalará claramente la experimental metodología seguida por Sarduy para obtener lo que consideramos ser una gran metáfora del mundo chino-cubano.

Al dar comienzo a "Junto al Río de Cenizas de Rosa", el escritor mezcla y yuxtapone una serie de signos que motiva el desarrollo cático pero lógico del relato. Con brochazos seguros, Sarduy (estudioso de la pintura) acumula imágenes alusivas y elusivas de grarı sabor erótico. Crea una sucesión de sintagmas que proyecta imágenes de animales y fenómenos naturales que establecen la atmósfera adecuada para el primer encuentro del libidinoso General con Flor de Loto. Como en un cuadro erótico de un artista chino, la primera escena que se vislumbra es la de un jardín, un bosque habitado por garzas, perdices, culebras, tortugas, unicornios y, sobre todos ellos, la luna blanqueando los helechos (25). En su conjunto, el paisaje no forma una imagen realista--se mezcla lo chino con lo cubano, lo real con lo mitológico--, pero sí una metáfora de la presencia del elemento yang y yin, masculino y femenino, y, por lo tanto, de la posible unión del General con la amarilla.

Aunque dicha unión nunca se lleva a cabo, los signos eróticos despiertan la pasión del General. Recordemos que en la antigua cultura china era común estar expuesto a imágenes de cuadros, objetos de arte, platos y otras manifestaciones artísticas que estimulaban las fuerzas vitales del yang y del yin. Como el arte del coito era parte integral de su sistema, los chinos consideraban este tipo de estimulación erótica perfectamente normal y necesaria. La poesía, el arte en general, se nutría de símbolos que expresaban por analogía o semejanza las partes genitales del cuerpo humano, así como su secreción.durante el acto copulativo. Teniendo esto en cuenta podemos observar que, en los párrafos introductorios de "Junto al Río de Cenizas de Rosa", Sarduy ha conglomerado una serie de imágenes que inadvertidamente muestra la importancia del erotismo en la cultura china. La luna de la primera página no es solamente la típica luna china que aparece en repetidos cuadros del oriente, sino también la metáfora del glúteo femenino; la tortuguita viene a ser un signo erótico o una metáfora (cuando la consideramos junto a la serpiente) de la fecundación del elemento femenino por el masculino; el unicornio es un emblema del elemento yang, un

3 Emir Rodríguez Monegal, "Las estructuras de la narración", diálogo con Severo Sarduy en Mundo Nuevo, núm. 2 (agosto 1966), p. 19. 
símbolo de fertilidad al lado de una garza rosada: el elemento yin. En medio de este bosque de señales eróticas se encuentra Cenizas de Rosa, la amarilla: "Cosida en aquel paisaje, ejercitando su yin en pleno bosque de La Habana, era un pájaro blanco detrás del bambú, un prisionero inmóvil entre lanzas'' (25).

La inmovilidad de la china es temporal. Es sólo una instantánea fotográfica en su proceso de evolución hacia imágenes que parecen reales, palpables algunas veces, para luego desaparecer como un espejismo y sólo dejar la huella de un deseo insatisfecho. La china, como objeto del deseo del General, es polimorfa : una máscara blanca, un soplo que pasa, una imagen escurridiza que desorienta al General. La oriental no se fija, es "mimética":

La denuncian sus ojos, dos ranuras doradas, ojos de encantador de serpientes. Caimito sobre los ramos de caimito. Es mimética. Es una textura--las placas blancas del tronco de una ceiba--, una flor podrida bajo una palma, una mariposa estampada de pupilas, es una simetría pura. ¿Dónde está? No la veo. Respira apenas. Ahora, con su pincel de cejas se dibuja caras en las manos y las agita lejos de la suya, para así aturdir al Belicoso (26).

El objeto erótico se transforma en proporción directa con el deseo del militar. Carece de autonomía y se adapta a la situación que lo determina. Es una apariencia que se confunde con el espacio que lo rodea, que se niega. Es un signo variable, una ilusión óptica que, en la distancia, es producto de la imaginación febril del General y que, al fulgor de su mirada, se refleja en la naturaleza convirtiéndose en "textura", desvaneciéndose sin llegar a satisfacerlo.

El deseo del General, como catálisis que alienta sus acciones libidinosas, se manifiesta por medio de imágenes de orden bélico-- "se abría paso entre la zarza entonando un aire de combate" (26)--que establecen analogías entre el combate y el erotismo. Cuando cree tener acorralada a la china y se siente en la cúspide de su excitación, es descrito como un mercenario en combate:

El Matarife está listo para la pelea. Para él, las fugas son como los carros llenos de oro que se regalan a un invasor para detenerlo. Da vueltas y vueltas en torno a su presa: no es ya una, sino dos espadas las que lleva. Con el segundo cuchillo, el que se dobla pero no se parte, abre la maleza. ¡Flautica pírrica ésa! (27)

Como es evidente, el General es portador de dos espadas: la militar y la somática, "la que se dobla y no se parte'. Mientras más ligera es la imagen de la china, más se ilusiona el General, y más patente es la alusión al sexo: "Mientras más se sutiliza la amarilla, más líquida se vuelve, la espada que sabéis más ígnea; jya es casi bifida! (27). A pesar de que no hay una sola referencia directa al sexo, sabemos que la espada del General está lista para llevar a cabo el "jaque mate", es decir, el acto copulativo. Al utilizar lo lujurioso como eje semántico entre unidades de distinto significado, Sarduy consigue subrayar el deseo que rige la narración de este primer episodio. 
Dada la importancia de la persecución de Flor de Lotố de parte del General, el escritor cubano persiste en establecer unidades de significado en torno a ejes semánticos que connoten significaciones eróticas. Los signos siguen, por lo tanto, aflorando al compás del relato, pero no son ahora del mundo chino, sino de escenas habaneras. Cuando Auxilio y Socorro se sitúan ante un afiche de pasta dental, el General no puede retener la lujuria que le despierta la posición de "Las Peripatéticas" en relación con el anuncio dentífrico:

¿Qué bien les queda todo! Paradas en una esquina, en plena oferta y demanda ante un afiche de pasta Gravi (la reina de las cremas dentales) quedan entre el cepillo de dientes gigance y la espiral rosada.

Se acerca el General. Con una publicidad así, ¿cómo va a resistirlas? (37)

Aquí la "espada bífida" es substituida por una "espiral rosada". Esta última surte el mismo efecto que la alusión bélica porque también expone la sed erótica del libidinoso. Es significativo, entonces, que casi cualquier imagen colocada en un contexto erótico connota el deseo latente del personaje.

A medida que continúa la narración los signos eróticos se hacen más evidentes y culminan con la elaborada descripción del falo de un marinero norteamericano que ha conseguido los favores de María Eng, el doble, el simétrico, la ausencia de Flor de Loto. Los amantes están en un reservado tocándose y besándose, mientras Carita de Tortura los dibuja en un fresco. El General, excitado y escondido, los ve reflejados en los espejos:

Es un reservado oscuro, con olor a humo de Camel mentolado. Cuatro sofás de cuero negro en los ángulos. Espejos. En una pared gue ilumina una lamparita blanca, un hombre pinta. Enfrente--G. los ve reflejados--, María e il rosso se besan; están sentados uno al lado del otro y miran la pared (donde el fresco se va definiendo). Se acarician y sonríen. El le muestra su sexo, rosado y perfectamente cilindrico. El glande es un caracol o una cúpula rayada en blanco y en el amapola fluorescente de la camisa, como un caramelo o un reguilete. María lo toca con la punta de los dedos. Risita. (43)

La imagen (enmarcada en los espejos y en el fresco) de las caricias preliminares del acto copulativo entre María Eng y el marino tiene la misma función de los cuadros eróticos de la China antigua a que aludimos anteriormente. En ambos se ilustran con profusión de detalles los órganos genitales de los participantes con el fin de exaltar el deseo del observador. Aquí el escritor logra comunicar la impresión de reproducciones simétricas de la postura amorosa que se multiplica y expande a marcos más amplios al reflejarse en los espejos y en el fresco.

Al mismo tiempo que se crea la ilusión de reflejos en los vidrios, Sarduy introduce otro elemento que reduce la atención del norteamericano y del lector a un punto diminuto en el cuerpo de María. No son sus intimidades las que más se destacan, sino más bien el cuadro que Carita de Tortura le ha tatuado en el ombligo, y cuyo original ella atribuye al paisajista chino Li Sung. La descripción del torso de la oriental se ha ido concentrando 
paulatinamente en un punto definido: de los senos en la parte superior al ombligo cerca del sexo:

Le muestra ahora sus senos, igualmente decorados: una espiral amarilla parte de los pezones y se pierde en el pecho; le muestra su ombligo: pintada, la reproducción en miniatura de un tondo cóncavo. Johnny se pega contra el vientre para verlo. Un mar embravecido ocupa casi toda la media esfera--líneas continuas en tinta negra, como las vetas de un árbol--, en él se distingue apenas una barca. A la derecha un farallón, rocas que ciñe la espuma, un cielo con cuños rojos. (43)

El paisaje en su conjunto--el mar con su textura de líneas en tinta negra, farallón, la espuma, el cuño rojo--tiene significación erótica. La descripción pone de manifiesto el nexo que, para los chinos, existe entre el cuerpo y la naturaleza, ${ }^{4}$ así como también se hace patente la relación sarduyana entre el cuerpo y la escritura, entre cuerpo y erotismo.

Volviendo al cuadro de Li Sung, es apropiado anotar que los paisajes chinos carecen de realismo. Son, por el contrario, metáforas de una realidad cósmica en la cual se conjugan constantemente el yin y el yang. De manera que cuando la lluvia (jugo del cielo) atraviesa las nubes (esencia de la tierra) se pone de manifiesto la relación entre el hombre y la mujer, masculino y femenino. En la China antigua existía la creencia de que el hombre había pertenecido en un principio al todo cósmico del cual se había visto separado temporalmente. Por eso era común tener presente la visión de un jardín, cuadro, biombo o almanaque de paisajes que recordaran la naturaleza salvaje y el sentido final de la copulación: recrear, al nivel humano, la unión de sus fuerzas primarias del yang y del yin, del cielo y de la tierra. ${ }^{5}$ Por medio de la reproducción del cuadro de Li Sung en el ombligo de María, Sarduy ha podido concentrar en ese punto diminuto la naturaleza con su significado erótico. ${ }^{6}$

Es notorio que los signos que delatan el erotismo de la sección china han evolucionado paulatinamente desde un plano casi mítico e indirecto (la selva y el bosque de imágenes de animales) a otro de alusiones bélicas y comerciales más definidas y directas (la espada y los afiches de las calles del barrio chino), que ya preludian la denominación especifica del órgano genital del norteamericano que acompaña a María. Este momento en que se definen los signos es también testigo de la inversión que se efectúa en el papel asignado al General,

\footnotetext{
4 Para alusiones al cuerpo como alegoría de la naturaleza, véase Octavio Paz, "Alquimia sexual y cortesía erótica", en Conjunciones y disyunciones (México: Joaquin Mortiz, 1969), p. 95 y ss.

5 Véase Phillip Rawson, Erotic Art of the East (New York: G.P. Putnam's Sons, 1968), p. 255.

6 El grabado del mar embravecido en el cuerpo de la oriental, también delata una técnica que el escritor ha estudiado en detalle en la novela Compacto de Maurice Roche, donde es evidente la relación literatura/tatuaje. Uno de los personajes de Compacto es un médico japonés que colecciona pieles y quiere la de un ciego moribundo que está tatuada y llena de jeroglíficos. Sarduy indica que la literatura debe ser como lo que practica el médico japonés porque "...un arte del tatuaje: inscribe, cifra en la masa amorfa del lenguaje informativo los verdaderos signos de la significación...Para que la masa informativa se convierta en texto, para que la palabra comunique, el escritor tiene que tatuarla, que insertar en ella sus pictogramas". Escrito sobre un cuerpo (Buenos Aires: Editorial Sudamericana, 1969), p. 52. En adelante usaremos entre paréntesis la abreviatura $E$ seguida de la página correspondiente para indicar las citas de esta edición. Teniendo en cuenta las palabras de Sarduy, podemos considerar el cuadro incrustado en el cuerpo de la oriental como un pictograma tatuado al mismo nivel que los otros grafos y cuya función es la de subrayar sutilmente la ya mencionada relación entre la naturaleza y el cuerpo, entre literatura y tatuaje, entre cuerpo y erotismo.
} 
quien, como hemos dicho, pasa de perseguidor-mirón a perseguido-torturado.

En el momento en que Auxilio y Socorro delatan la presencia del Mirón, éste se encuentra en estado de excitación extrema a causa de la escena amorosa entre María y el norteamericano--“ "...de la pura contemplación, ya había pasado a la praxis da solo"' (44). Así lo sorprende Carita de Tortura, quien lo increpa y finalmente lo tortura. La aparición de Carita de Tortura no es gratuita. María Eng señala que él es "muy antiguo maestro en las artes simétricas del placer y el horror de los ojos: Pintura y Tortura chinas"' (44). Las palabras de la doble de Flor ponen de relieve dos factores importantes y bien conocidos con respecto a la antigua cultura china: el arte del coito y la aludida tortura. El pintor (Carita de Tortura) parece ser conocedor de libros eróticos como el Fang-nei y el Fang-shi, donde se ilustran las diferentes posiciones del acto sexual y se enumeran detalladamente las reglas que debian seguirse para prolongar el coito y obtener la mayor satisfacción posible. Estos libros señalan hasta el ritmo que debe seguirse durante la copulación, y muchas veces la gran abundancia de ilustraciones artísticas ("arte simétrico del placer") sugiere la importancia del movimiento rítmico del acto sexual.

La presencia en esta parte del relato de una mezcla de placer y dolor es evidente. Es aquí, por tanto, donde se ve claramente el rol sádico que tiene el General al final de "Junto al Río de Cenizas de Rosa". El Mirón contempla con placer la idea de herir a Flor cuando se da cuenta de que no puede saciar su pasión. Quizás haya comprendido durante su tortura que "el placer está atravesado por el dolor" (53).

En su artículo "Del yin al yang", Sarduy ha señalado varias de las características del sistema sádico que pueden relacionarse con el cambio que se efectúa en el irrisorio General. El escritor cubano apunta, entre otras cosas, que el sádico reduce su sistema a la repetición. Tiene que crear condiciones óptimas para satisfacer sus deseos y por ende se vale de un código inflexible de posiciones y gestos. Espera en su ensayo diario de cada noche la formación de "esa escena en que la realidad será el dibujo de su deseo" $(E, 14)$. Barthes, a su vez, ha indicado que el ensayo diario de Sade está regido por un ordenador (director) que impide que los participantes se salgan del orden erótico. ${ }^{7}$ El código está compuesto de unidades sometidas a reglas de combinación o de composición. La unidad mínima es la postura. Cuando éstas se combinan forman una categoria superior: la operación. En un conjunto simultáneo de posturas, la operación se denomina figura; pero si se percibe como sucesión de posturas (unidades diacrónicas) recibe el nombre de episodios. Si estas operaciones se extienden y se suceden, forman la unidad mayor de la gramática erótica: la escena. ${ }^{8}$ El héroe sádico espera que la representación de esta escena coincida con la urgencia de su deseo. Por tal razón, el General va todos los días a ver "La Toma" , la obra de teatro en la que participa la amarilla: "Siempre en primera fila. La aparición de Flor en la Toma del Fuerte es la fiesta de los Posibles" (49). Se sabe la obra de memoria, pero persiste en sus visitas para ver a Flor de Loto " ....sosteniendo en una.mano el Fénix imperial, flanqueada por dos unicornios...en plena posesión de su yin..." (51). Asiste ritualmente al teatro burlesco como se asiste a una misa (49), porque cree que en la repetición de la misma escena (ritual) se llega a crear la condición óptima donde podrá ver

8 Roland Barthes, “El árbol del crimen", Mundo Nuevo, núm. 16 (octubre 1967), p. 42.

8 Barthes, pp. 42-43. 
su deseo satisfecho. ${ }^{9}$

No obstante su persistencia, el General no puede unirse con el objeto de su deseo ni extinguir su ansia de poseerlo. Acosa a Auxilio y a Socorro para que éstas le digan el paradero de la china. Quiere saber por qué no la puede tocar y hacerla suya. Las Cabecipeladas (Auxilio y Socorro) le repiten que Flor es sólo una apariencia, un secreto, y que por eso no podrá encontrarla. No comprende que desde su primera aparición Flor subraya su carácter decorativo, su apariencia, lo teatral, el hecho de que sólo es "un pellejo pintarrajeado", quizás un travestí. Aun cuando aparece en escena, la cara de la china, saturada hasta el límite de cosméticos y paramentos, es una máscara barroca e ilusoria:

En su rostro navegan peces, huyen mariposas negras sobre sus párpados. Le dividen la frente dos espirales blancas; dos orlas simétricas, negras y amarillas, parten del labio superior y, bordeando la nariz, se abren como caracoles en los pómulos. En las mangas hay pintadas dos máscaras iguales a su cara. (50)

Lo ilusorio es precisamente lo que alimenta el deseo del militar, para quien la única realidad es la lujuria que lo posee. Pronto, no obstante, se aferra a la idea de herir a Flor de Loto y completa su ciclo sádico al enviarle una pulsera de jade azul con un dispositivo interior, "que funcionaba al cerrarse la joya en la muñeca, y que soltaba dos navajitas de afeitar muy afiladas contra la parte interior del puño" (53). Ya no va al teatro, ahora "espera a que saquen por la puerta de los camerinos un cuerpo pálido" (54): la china muerta. Como ha indicado Sarduy en otro contexto, al destruir a Flor de Loto, el acto sádico substituye al de la posesión $(E, 45)$.

Una vez finalizado el ciclo sádico del General, consideramos imprescindible anotar que el deseo y sus proyecciones está constantemente erosionado por el choteo que inyecta el escritor, quien desde un principio nos pone en sobre aviso al asegurar que habrá un "poco de desorden en el orden" (28). De ahí que, por ejemplo, cuando describe despaciosa y contemplativamente la reunión detrás del fresco, aluda en forma burlesca al órgano genital de uno de los chinos allí reunidos: "( $\mathrm{S}$ í, tenía, pero pequeño y espiral como un tornillito)"'(47). La referencia es indirecta y el lector se cree hasta responsable ya que Sarduy se limita a decir que el chino está desnudo y a contestar entre paréntesis una supuesta pregunta del lector. Sarduy "echa a relajo" lo ocurrido, y la frágil anécdota de la novela se erosiona aun más con las constantes burlas propias del choteo cubano. Los personajes y el propio autor se burlan constantemente de su propio erotismo al poner en tela de juicio todas las imágenes eróticas que se han creado a través del relato sobre lo chino. Por lo usual, la pirotecnia verbal rebosa las frases para divertimiento del lector y aniquilación de cualquier resto de seriedad. Todo esto tiene, sin embargo, un orden preciso--las palabras surten el efecto deseado--porque si la escena refleja una erosión de la gravedad es debido a que está construída sobre una base sólida: el relajo con orden.

Ese deseo a que nos hemos referido es, a su vez, el eje alrededor del cual giran las otras dos características esenciales que Sarduy atribuye al mundo chino: estatismo y acción extrema. Las dos aparecen a través del relato mezcladas en una alternancia que, según

${ }^{9}$ Sobre la importancia de la repetición en el sistema sádico, véase Escrito sobre un cuerpo, pp. 13-15. 
afirma Rodríguez Monegal, recuerda las películas japonesas de Akira Kurasawa, donde la sucesión de escenas lentas y explosiones violentas de movimiento están motivadas por el deseo, la pasión criminal; pero que Sarduy relaciona más intimamente con la pintura, ${ }^{10}$ la cual tiene suma importancia en la concepción de esta metáfora chino-cubana. Veamos, pues, cómo se manifiestan esos dos elementos a que hemos hecho referencia ya que ellos, como ramificaciones del deseo, establecen el tempo de "Junto al Río de Cenizas de Rosa".

Del mundo de señales eróticas en que se encuentra por primera vez el General con la amarilla, la cadencia narrativa nos lleva a un procenio que contrasta momentáneamente con el bosque de las primeras páginas donde predominan la acción, el movimiento, ${ }^{11}$ las metamorfosis constantes de la china perseguida por el lujurioso militar. La fijeza que cierra el episodio de la persecución preliminar sirve de transición a la escena que nos adentra al barrio chino. Ahora se subraya lo extático e ilusorio del mundo de las drogas. Con las palabras “'A tmósfera china, muchachitas!" (28), Sarduy introduce al director de la Opera del "Shanghai", quien evidentemente está drogado.

El mundo extático de las drogas del que participa el director es posible gracias a las maniobras de Carita de Dragón, el distribuidor principal de todas las hierbas alucinatorias. Los cigarrillos de gajo (mariguana), los sobrecitos de azúcar refino (cocaina), así como el haschisch y el opio, abren las puertas al éxtasis; pero el mundo de contemplación y estatismo no está únicamente regido y limitado por los estimulantes oníricos que distribuye Carita de Dragón y consume, entre otros, el director del teatro burlesco. Se nota también en el modo narrativo. Por eso, cuando el General baja al sótano húmedo después de la tortura inferida por Carita de Tortura, la narración se hace más lenta y contemplativa. E1 ritmo de las frases carece del estímulo metamórfico propio del desenfreno, del tempo alla breve que caracteriza las transformaciones vertiginosas de la china y de Auxilio y Socorro.

El descenso al tren de lavado es como una penetración en lo más íntimo del mundo chino donde el General es sólo un intruso. Encerrado en un cuarto, lo único que ve a su alrededor es un fresco que decora las húmedas paredes y la puerta de madera del cuchitril en que se encuentra. El mural pone de relieve la quietud de esta sección antes llena de dinamismo y movimiento. La pared pintada capta un mundo fijo que representa a Carita de Tortura y sus súbditos: las dos Obesas, la Chon y la Si-Yuen (Auxilio y Socorro). Los que previamente estaban moviéndose de un lado a otro haciendo sus travesuras, ahora se ven petrificados en el fresco. Sin embargo, a ese mundo estático se yuxtapone nuevamente el de movimiento, un movimiento lento, pausado, en via de transformación. Detrás del fresco, en la habitación contigua, hay vida: los mismos constituyentes del cuadro se mueven muy parsimoniosamente debido a los efectos del opio que fuman sin cesar. La reunión, así como el fresco al otro lado del muro, representa más que nada la idea de contemplación.

La alternancia de escenas lentas (contemplativas) con otras de movimientos rápidos y violentos producidos por el deseo o la presencia de Auxilio y Socorro es de singular importancia. Phillip Rawson indica acertadamente que los chinos siempre han percibido la

\footnotetext{
${ }^{10}$ Rodriguez Monegal, p. 19.

${ }^{11} \mathrm{El}$ movimiento que se advierte al principio del relato se debe principalmente a la interacción del elemento masculino (yang) y del femenino (yin). La influencia recíproca de estas dos fuerzas produce una clase de movimientc) y cambio constante: "The virile and the docile displace each other and produce the changes and transformations..." Véase I Ching, trad. de la $2^{\mathrm{a}}$ ed. por James Legge (New York: University Books, Inc., 1964), p. xli.
} 
realidad como un tejido de movimiento y cambio: "The Chinese have always perceived the real as an immense web of movement and change. All apparently static and unitary objects are seen as patterns ( $l$ ) merely apparent in the process of continuous evolution". ${ }^{12}$ El estatismo de muchas partes del relato es, por ende, sólo un estado transitorio que desembocará en escenas más dinámicas. Aun las descripciones más tenues conllevan el germen de una continua evolución. Es evidente, entonces, que no es tanto la realidad externa de una escena lo que preocupa a Sarduy, sino más bien la captación del espíritu de la forma: su movimiento.

Relacionado con esta alternación en el tempo de las escenas, está el constante metamorfosearse de los personajes. Estos aparecen y desaparecen vertiginosamente bajo diferentes disfraces o entidades que delatan sus cambios sucesivos. El lugar par excellence para este tipo de transformaciones es precisamente el teatro erótico (de relajo) el "Shanghai"', donde se mezcla lo estático con lo desenfrenado. Sarduy ya ha indicado en uno de sus artículos sobre la literatura del futuro que este tipo de teatro es el lugar más propicio para engendrar una narrativa en la cual el lenguaje aparecería como "una superficie de transformaciones ilimitadas" $(E, 52)$. Esto explica por qué el escritor cubano consideró el teatro burlesco habanero como el lugar ideal para exponer sus teorías literarias y, al mismo tiempo, captar ese espiritu del mundo chino.

Auxilio y Socorro, artistas del teatro burlesco, son las víctimas más dinámicas de la metamorfosis que aflige a la asiática perseguida por el General. Como indica el narrador, son dueñas del "secreto de las setenta y ocho metamorfosis"' (29). Las divinidades calvas-así también conocidas--son capaces de adquirir diferentes y variadas entidades cuando el General las persigue. Tales transformaciones son las más propicias para establecer el carácter metamórfico de la sección china. En un mismo plano encontramos las más variadas combinaciones, las más extravagantes y vertiginosas mixturas que, en ocasiones, provocan una sonrisa incrédula en el lector. Auxilio y Socorro pueden convertirse en lo más extraño, en lo más esotérico, así como en lo más vulgar:

Son fluorescentes, son de acetileno, son tambores que imantan pájaros, son helicópteros, son sillas en el fondo de un acuario, son eunucos obesos con los sexos diminutos entre flores rosadas, son pirañas, son ángeles leprosos que cantan 'Metamorfosis, metamorfosis', son dos pobres criaturas...(36)

Es imposible alocar a Auxilio y a Socorro en una casilla determinada porque tan pronto se anulan por saturación, como remanecen vitalizadas. Son una secuencia incansable de transformaciones. Ninguna de éstas es la verdadera o la original: lo único que les importa (lo único que le interesa al lector), su única realidad, es la de las mutaciones. No son personajes à la manera tradicional: no tienen personalidad ni densidad sicológica. Solamente subrayan la Metamorfosis que llevan a cabo: son una sucesión interminable.

Aunque el General no se metamorfosea a través de las páginas de la sección china, el narrador describe sus gestos de varias maneras diferentes, dejando que el lector escoja la que más le sea afin. $\mathrm{Y}$ así, el uso del lenguaje figurado se expande hasta agotarse. Lo

${ }^{12}$ Rawson, p. 254. 
esencial del gesto se imprime en diferentes maneras. Cuando el General lleno de lujuria persigue a Maria Eng, Sarduy lo describe $\in n$ movimiento:

A toda máquina. Despega. Lebrel tras perdiz de hojalata, tigre tras torcaza a sí mismo fijada. Le rechinan los fémures. Sabueso. Con la lengua afuera. Gamo mojado. Franja de aros dispersos. Deja líneas negras. Perro de la Greyhound. Dragón de la Shell. (40)

Todas las imágenes de esta cita connotan algún tipo de movimiento o de persecución. En realidad, todas implican la expresión "a toda máquina", es decir, rápidamente. Son impresiones visuales que ayudan a comprender el movimiento rápido del General. Cuando éste vacila, se mueve inseguramente, Sarduy lo compara con una foto movida: "Zigzaguea G. Se sigue a sí mismo. Foto movida, va casi entero, más pálido, tras su propio cuerpo, y otra vez, borroso, detrás...y otra vez' (41). Aquí, hasta cierto punto, radica una de las principales virtudes del joven escritor cubano. Son tan sorprendentes, tan originales, $\tan$ humoristicas y $\tan$ vivas las comparaciones que se siente gozo en descubrir y penetrar el mundo de posibilidades que brinda un objeto, una acción o una descripción pictórica.

Las referencias que hemos establecido con facetas de la cultura china podrían ser interpretadas como un intento de mostrar una realidad foránea al relato. Pensamos, no obstante, que la realidad de "Junto al Río de Cenizas de Rosa" es autónoma y no necesita ser respaldada por ningún cosmos extranjero. Lo que hemos tratado de hacer con nuestras referencias a universos exteriores es dilucidar las proyecciones y ramificaciones del deseo en el relato. Porque si es verdad que el deseo es el eje principal del cual emanan los demás acontecimientos de la narración, también es verdad que este mundo de deseo tiene una relación directa con el mundo del que Sarduy nos ha brindado una metáfora muy personal. Lo mismo se podría decir de las constantes transformaciones de los personajes femeninos: son necesidades propias de la escritura de "Junto al Río de Cenizas de Rosa", pero, al mismo tiempo, mantienen una línea conexiva con un mundo propiamente chino que, aunque no es el mismo del relato, ayuda a sostener la fantástica creación literaria. Las alusiones, en las primeras páginas, a las fuerzas primarias--yang/yin--por muy aisladas que estén dentro del marco imaginario del relato, se ven respaldadas por un sistema que propone los mismos resultados que consigue el escritor.

Virginia Polytechnic Institute and State University University of Kentucky

JUSTO C. ULLOA LEONOR A. DE ULLOA 